Lucyna Kopciewicz

Uniwersytet Gdański

\title{
Natura i równość - panika moralna wokół porażek szkolnych chłopców w latach 90. XX wieku w perspektywie niepokojów wokół feminizmu i posthumanizmu w XXI wieku
}

Do niedawna pojęcie paniki moralnej funkcjonowało w obszarze zachodnich nauk społecznych. Obecnie - z racji kreowanej przez media atmosfery niepokoju wobec zjawisk równościowych - pojęcie to zaczyna adekwatnie nazywać fenomeny społeczne rozgrywające się w Polsce. Celem niniejszego tekstu jest przyjrzenie się jednej z wcześniejszych odsłon paniki moralnej świata zachodniego (Wielka Brytania, Stany Zjednoczone i Australia), jaka wiązała się z odkryciem szkolnej porażki chłopców. Omówiona zostanie jej istota i najważniejsze tematy, które poruszały tamtejszą opinię publiczną w związku z ogłoszonym wówczas „kryzysem męskości”. Następnie nakreślone zostaną podstawowe parametry dwóch współczesnych odmian paniki moralnej: kryzysu tożsamościowego $\mathrm{w}$ związku z postępami genderowego dyskursu równościowego oraz niepokoju $\mathrm{w}$ związku z problemami podnoszonymi na posthumanistycznym gruncie. Istota tego tekstu nie wiąże się jednak z zabiegami archiwizowania społecznych niepokojów przeszłości czy współczesności. Proponuję, by omawiane przykłady paniki moralnej traktować jako typy sprowokowanych lękowych reakcji w związku ze zmianami społecznymi i postępującą równością. Próbę powstrzymania owych zmian niektórzy komentatorzy współczesności wiążą ściśle z pojęciem „natury”, w której upatrują gwaranta niezmienności dawnego porządku społecznego. Tym samym wyraźnie antagonizują naturę i dyskurs równości.

Zainteresowanie zjawiskiem niepokoju społecznego (paniką moralną) obserwuje się od lat 70. XX wieku. Teorię paniki moralnej rozwinął w 1972 roku Stanley Cohen, analizując reakcje mediów na zamieszki wywołane przez młodzieżowe gangi. Sposób relacjonowania tych zamieszek przez media wywołał reakcję w postaci wzmożonego lęku wokół samej młodzieży. Cohen zdefiniował panikę moralną jako uruchomienie tak zwanych stereotypów moralnych przez media wobec opisywanego zjawiska, czego efektem jest specyficzne wyolbrzymienie jego skali 
(przedstawienie go jako groźniejszego, o rozleglejszych skutkach, większej sile itp.). Jak przekonuje autor, panika moralna pozostawia pewne trwałe ślady instytucjonalne, w postaci nowych instytucji, regulacji lub przepisów prawa (Zielińska 2004, s. 161). Zdaniem Macieja Soina panika moralna jest efektem działania dominujących struktur społecznych, mających zdolność narzucania norm porządku społecznego, przez co wydarzenie ją inicjujące może - na skutek medialnej obróbki - przybrać nierzeczywiste, wyolbrzymione rozmiary i funkcjonować jako zagrożenie dla uznanych wartości społecznych (Soin 2011, s. 154).

Badacze zjawisk paniki moralnej wskazują, że ma ona strukturę fali - przybiera na sile, osiąga swój punkt kulminacyjny i wygasa (zanika). Jednak nie zanikają wniesione przez nią efekty. W następstwie działania paniki moralnej zostają bowiem wytyczone (i umocnione) granice moralne społeczeństwa. Owo wytyczenie i umocnienie zachodzi poprzez liczne działania stygmatyzacyjne oraz piętnowanie grup społecznych, przedstawianych w mediach jako moralnie złe.

\section{Panika moralna wokół porażek szkolnych chłopców}

W latach 90. XX wieku zachodnioeuropejskie, amerykańskie i australijskie badania edukacyjne zdominowane były przez problematykę społecznej, kulturowej, szkolnej, ekonomicznej i politycznej marginalizacji dziewcząt (kobiet). Problem szkolnego funkcjonowania dziewcząt pojawił się w nich (badaniach) jako jedna z głównych przyczyn utrzymywania się nierównego statusu kobiet i mężczyzn we współczesnych społeczeństwach zachodnich. $Z$ tego względu szkoły w tamtejszych społeczeństwach stały się terenem edukacyjnych i emancypacyjnych działań podejmowanych na rzecz dziewcząt (Arnot, Gubb 2001). Badaczkom feministycznym udało się zidentyfikować i opisać szereg niekorzystnych zjawisk, procesów i mechanizmów funkcjonujących w szkolnej przestrzeni, których efektem jest odtworzenie struktury społecznych nierówności (nierównego statusu kobiet i mężczyzn). Prace feministyczne diagnozujące przyczyny, w tym przyczyny o charakterze edukacyjnym, okazały się bardzo pomocne w projektowaniu wielu „działań naprawczych" i inicjatyw edukacyjnych, takich jak: inkluzywne programy nauczania, programy antydyskryminacyjne, programy wpierające niestereotypowe zainteresowania szkolne dziewcząt $w$ takich dziedzinach, jak matematyka, fizyka czy informatyka (Rogers, Kaiser 1995). Prace feministyczne przyczyniły się również do postawienia w centrum debaty publicznej problemów emancypacji marginalizowanych grup społecznych, problematykę równych szans i sprawiedliwości oraz społecznej troski o grupy najsłabsze (w znaczeniu kulturowym i politycznym). Wszystkie wspomniane działania tworzyły grunt dla zasadniczej zmiany szkolnego funkcjonowania dziewcząt - ich szkolnego sukcesu (Marry 2007) i zmiany funkcjonowania zawodowego kobiet w Europie Zachodniej: zachowywania ciągłości zatrudnienia mimo macierzyństwa (Maruani 2007). W tym samym czasie na marginesie debaty o szkolnym funkcjonowaniu dziewcząt zaczyna narastać przekonanie o konieczności zwrócenia większej badawczej 
uwagi na kwestie związane z męskością i mężczyznami w edukacyjnych odniesieniach (Kimmel 2000; Mac an Ghaill 1996; Weaver-Hightower 2003): na szkolne funkcjonowanie chłopców, ich osiągnięcia, niepowodzenia szkolne, przemoc i agresję, destrukcyjne zachowania i szkolne skutki socjalizacyjnego treningu męskości. W wielu krajach, zwłaszcza w Wielkiej Brytanii, Stanach Zjednoczonych i Australii "problem chłopców” pojawił się w mediach w atmosferze paniki moralnej (Kopciewicz 2012, s. 55). Uczestnikami debaty na temat szkolnego funkcjonowania chłopców i ich szkolnych niepowodzeń było środowisko nauczycielskie, działacze oświatowi, stowarzyszenia rodziców, politycy, działacze religijni, aktywiści ruchu mniejszości seksualnych i innych ugrupowań mężczyzn, psychologowie i terapeuci. Efektem wzmożonego zainteresowania mediów tematem "chłopcy" było wiele publikacji o pop-socjologicznym lub pop-psychologicznym charakterze. Ich wspólną cechą był alarmistyczny ton i przekonanie o społecznej katastrofie wywołanej szkolnymi niepowodzeniami chłopców.

„Problem chłopców” zaistniał w niedługim czasie również jako przedmiot naukowych rozważań. Ich efektem były publikacje o charakterze teoretycznym, diagnozującym sytuację tej grupy uczniów, oraz praktycznym - projektującym liczne działania „naprawcze”. Warto jednak podkreślić, że naukowe środowisko badające problematykę męskości i edukacji dzieli jedna zasadnicza kwestia - stosunek do feminizmu, a zwłaszcza stopień akceptacji retoryki backlashu. Backlash odnosi się do fali prawicowego uderzenia w feminizm i jego zdobycze w sferach społecznej, kulturowej i politycznej oraz w edukacji, które miało miejsce w latach 80. i 90. XX wieku. Częścią backlashowej retoryki stały się hasła powrotu do naturalnego porządku rzeczy, przywrócenia zaburzonej równowagi, wycofania kulturowych zdobyczy progresywnych ruchów społecznych (w tym ruchu feministycznego) jako sztucznych wsporników „fałszywie pojmowanej równości” (Faludi 1991). Edukacyjną odsłoną backlashu w Stanach Zjednoczonych, Australii czy Wielkiej Brytanii była debata, którą znawcy przedmiotu określają mianem debaty wokól pytania: „What about the boys?” (Kimmel 2000). Jej istota sprowadzała się do „odzyskania pola” i przywrócenia przewagi chłopców w sferze edukacyjnej, która to przewaga została zniwelowania na skutek wojny wypowiedzianej chłopcom (Sommers 2000). Natomiast przeciwników backlashu, którzy podjęli badanie problematyki męskości i edukacji w trosce o demokratyczne wartości i włączenie „problematyki chłopców” w debatę o równości płci, określa się jako uczestników "The boys turn" (Mac an Ghaill 1996; Weaver-Hightower 2003).

Michael S. Kimmel i Marcus Weaver-Hightower wskazują, że źródłem zwiększonego zainteresowania naukowego środowiska badającego problematykę gender w edukacji było pojawienie się pop-psychologicznych i pop-socjologicznych publikacji poświęconych chłopcom. Publikacje te utrzymane były w klimacie paniki moralnej i obwieszczały „kryzys męskości” jako jedną z odsłon poważnego kryzysu społecznego; kryzysu, który ma swoją wyraźną przyczynę i w związku z tym - winnych i społecznie odpowiedzialnych, których trzeba rozliczyć. Martin Mills, opisując atmosferę backlashu, używa określenia backlash blockbusters, zwracając uwagę na rewanżyzm, klimat rozliczeń i napięcie wokół feminizmu (Mills 
2000). Inną pracą z nurtu popularnonaukowych analiz była praca Williama Pollacka zatytułowana Real Boys (Pollack 1998). Autor wskazywał na szkody psychiczne, których doznają chłopcy i młodzi mężczyźni żyjący we współczesnych społeczeństwach zachodnich w dobie późnego kapitalizmu. „Kastracyjne” potencjały współczesnej kultury, zdaniem autora, dają znać o sobie w postaci: wzrastającej liczby samobójstw chłopców i młodych mężczyzn, depresji, uzależnień od substancji psychoaktywnych, aktów przemocy oraz gwałtownie narastającej fali niepowodzeń szkolnych tej grupy. Podobną pop-psychologiczną analizę rozwinęła Christina Hoff Sommers w szeroko komentowanej książce pod tytułem The War Against Boys. Autorka zwróciła uwagę na szereg niekorzystnych zjawisk odnoszących się do szkolnego funkcjonowania chłopców - niepowodzenia szkolne, porzucenie nauki szkolnej, dyscyplinarne usunięcia ze szkoły, agresja i przemoc. Autorka zidentyfikowała źródło tych niepowodzeń w feminizmie, który - jej zdaniem - w sferze edukacyjnej wysunął na pierwszy plan kwestię sukcesu szkolnego dziewcząt, co - zdaniem autorki - doprowadziło do „patologizacji” męskiej natury chłopców (Sommers 2000). Bardzo podobne rozważania zaprezentował guru tzw. edukacji zróżnicowanej ${ }^{1}$ Michael Gurian. Autor domagał się, by amerykańskie szkolnictwo było skrojone „na miarę” zróżnicowanych mózgów kobiecych i męskich, zróżnicowanych płciowo potrzeb i możliwości edukacyjnych poszczególnych grup. W obecnym kształcie, jak przekonywał autor, sfeminizowana szkoła szkodzi męskiej naturze chłopców, prowadzi do ich udziewczęcenia i odarcia ze wszystkiego, co męskie. Te „ciche zabójstwa” rozgrywają się codziennie w szkolnej przestrzeni i są wykonywane rękoma kryptofeministycznych lub jawnie feministycznych nauczycielek (Gurian 2001). Taki sam typ krytyki szkoły rozwinął Steve Biddulph w Australii. Argumenty autora osadzone są w esencjalistycznej koncepcji płci (testosteron i związane z nim naturalne potrzeby rozwojowe chłopców) i konserwatywnej, rewanżystowskiej koncepcji polityki edukacyjnej (Biddulph 1998). Prace Biddulpha, podobnie jak Guriana, Sommers i Pollacka wpisywały się w retorykę „,wojny płci”, „,wyrównania rachunków”, , pokazania feministkom, gdzie ich miejsce” i proklamowały powrót "naturalnego porządku płci”, a wraz z nim biologicznego determinizmu, bożego planu i innych argumentów o wyraźnie pozaspołecznym charakterze.

Pewien grunt dla zintensyfikowanego zainteresowania problematyką szkolnego funkcjonowania chłopców przygotowały również badaczki feministyczne, eksplorujące nieprzerwanie od lat 70. XX wieku problem ról płciowych (gender). Prace feministyczne wskazały, w jaki sposób kształtują się role płciowe i w jaki sposób we współczesnych społeczeństwach dokonuje się modyfikacja i zasadnicza rekonstrukcja ról kobiecych, jak emancypacja kobiet staje się faktem. Z tego względu wielu badaczy problematyki męskości (nawet jawnie antyfeministycznych) odwoływało się do feministycznej teorii ról płciowych w celu dokonania

Koncepcja segregacji płci w nauczaniu ufundowana na przekonaniu o poszanowaniu naturalnych różnic płci. Płciowe zróżnicowanie ma zdaniem zwolenników edukacji zróżnicowanej istotne konsekwencje edukacyjne w postaci płciowo stypizowanych strategii uczenia się, tworzenia wiedzy i - najogólniej - dotyczy wszystkich procesów poznawczych. 
analizy rodzinnych, ekonomicznych, społecznych i fizycznych aspektów życia mężczyzn w kontekstach: pracy, emocji, zdrowia, obrazu ciała, rozwodów, opieki nad dziećmi, przemocy i wielu innych (Farrell 1993). Wymowa wielu z tych prac zachowuje specyficzną warstwę retoryczną radykalnej teorii feministycznej lat 70 . XX wieku, gdzie miejsce kobiety - ofiary patriarchalnego społeczeństwa - zajmuje mężczyzna - ofiara opresyjnej socjalizacji (Kindlon, Thompson 2000). Jak z kolei przekonują Jane Kenway i Sue Willis, jedną z wielu przyczyn zwiększonego zainteresowania chłopcami jako „wielkimi przegranymi” szkolnego wyścigu było nieostrożne i niekrytyczne posługiwanie się tak zwanymi wskaźnikami równości płci w edukacji, zwłaszcza wynikami testów osiągnięć szkolnych i wskaźnikami reprezentacji płci w populacji osób uczących się/studiujących. Bezkrytyczna wiara w te dwa wskaźniki doprowadziła do przedwczesnych proklamacji „sukcesu szkolnego dziewcząt”, a nawet ogłoszenia przez niektórych socjologów „kresu nierówności płci w edukacji" (Kenway, Willis 1998). Co więcej, rozpowszechnienie się tej wiary w środowisku socjologów edukacji sprawiło, iż w momencie, w którym dziewczęta w Stanach Zjednoczonych, Australii czy Wielkiej Brytanii zaczęły osiągać lepsze niż chłopcy wyniki w szkolnych testach matematycznych, pospiesznie ogłoszono „kryzys męskości”.

Kolejnym istotnym czynnikiem intensyfikującym zainteresowanie badawcze problematyką męskości i edukacji były neoliberalne reformy edukacyjne (podjęte w latach 80. XX wieku w Wielkiej Brytanii przez rząd Margaret Thatcher czy w Stanach Zjednoczonych podczas prezydentury Ronalda Reagana). Nie chodzi jedynie o jawną antyemancypacyjną wymowę podejmowanych reform, ale przede wszystkim o strukturalny aspekt owych reform - powiązane procesy prywatyzacji, konkurencji wspartej na obiektywizujących procedurach w postaci standaryzowanych testów osiągnięć szkolnych i konstrukcji edukacyjnego rynku. Neoliberalne reformy edukacyjne w Wielkiej Brytanii miały poważne konsekwencje z punktu widzenia problematyki płci (i w jeszcze większym stopniu etniczności). Z uwagi na to, że chłopcy zdecydowanie celowali w kategorii najniższych osiągnięć szkolnych, zaczęli być postrzegani jako zagrożenie dla lokalnej, szkolnej polityki „zarządzania jakością” (poprawiania miejsca szkoły w rankingach). Ten nowy sposób traktowania chłopców doprowadził wielu brytyjskich działaczy oświatowych do podejmowania kwestii równości płci w edukacji z myślą o chłopcach nowych ofiarach opresyjnego rynku edukacyjnego (Lingard, Douglas 1999).

Jak już wspomniałam, backlash jest traktowany przez wielu badaczy problematyki męskości w edukacji jako jeden z ważniejszych czynników intensyfikujących badawcze zainteresowanie chłopcami. Backlashowa retoryka ujmowała szkolne funkcjonowanie dziewcząt w kategorii wyścigu i rywalizacji zakończonej sukcesem - zwycięstwem nad chłopcami. Taki wydźwięk debaty skutkował szeregiem jawnych ataków na feminizm i jego wypływy na szkolną rzeczywistość przez postulaty głoszące konieczność zmiany „kobiecej natury” współczesnej szkoły. Do najważniejszych prac analizujących zjawisko backlashu można zaliczyć pracę R. Lingard i P. Douglas (1999), które przeanalizowały backlash działający w postaci polityki edukacyjnej. Istotna jest również praca autorstwa Kenway 
i Willis (1998), które dokonały analizy bakclashu w oddolnej, szkolnej perspektywie - z punktu widzenia lokalnych działań "odporowych" podejmowanych przez nauczycieli, nauczycielki, szkolnych koordynatorów programów równościowych oraz uczniów i uczennice w kontekście prawicowych reform edukacyjnych.

Zmiany ekonomiczne prowadzące do głębokich zmian dotyczących pracy i sfery zatrudnienia wniosły sporo modyfikacji w polityce tożsamościowej, w tym polityce płci. Jak przekonują autorzy licznych prac, późnokapitalistyczne spoleczeństwa i model postfordowskiej siły roboczej doprowadził do zasadniczego zwrotu w kierunku feminizacji zatrudnienia (Maruani 2007). Ponadto kultura miejsca pracy $\mathrm{w}$ "nowym kapitalizmie" w znaczącym stopniu dowartościowuje "kobiece" sposoby działania, na przykład sieci współpracy, oddalając model działania oparty na jednostkowej rywalizacji i indywidualnych osiągnięciach jako ekonomicznie nieefektywny. W tym nowym kontekście, jak słusznie zauważa Madeleine Arnot, współczesna szkoła zupełnie się nie odnajduje, bowiem nie przygotowuje współczesnych mężczyzn nawet $\mathrm{w}$ najmniejszym stopniu do radzenia sobie $\mathrm{z}$ tymi zmianami, zwłaszcza zmianami $\mathrm{w}$ sferze tożsamości zawodowych oraz kruszącej się koncepcji dominującego patriarchy (Arnot, Gubb 2001, s. 125). Kulturowa zbędność hegemonicznej koncepcji męskości bywa opisywana w literaturze przedmiotu jako światowy kryzys męskości wywołany czynnikami makrospołecznymi (Melosik 2006; Mac an Ghaill 1996). Susan Faludi opisała bardzo wnikliwie kryzys amerykańskiej męskości jako złamaną obietnicę związaną $\mathrm{z}$ „patriarchalną dywidendą", gwarantującą mężczyznom w dość długim okresie przewagę nad kobietami w każdej ze sfer życia społecznego (zwłaszcza zawodowego i w polityce). Złamanie obietnicy przewagi skutkowało - zdaniem Faludi - falą męskiej przemocy w rodzinnym, szkolnym i społecznym wydaniu (Faludi 1999). Skala kryzysu dotykającego głównie młodych mężczyzn, doświadczających wykluczenia ekonomicznego i obywatelskiego, stale się rozszerza. Jak przekonywały Judith Butler czy Susan Sontag, wyjątkowo brutalnymi objawami tego kryzysu są zrytualizowane próby restytucji „prawdziwej męskości”, które można było prześledzić w mediach relacjonujących amerykańskie operacje militarne, a zwłaszcza skandale związane z torturowaniem jeńców wojennych (Abu Ghraib), ataki armii amerykańskiej na cywili ( $w$ tym dzieci) czy szeroko komentowana fala przemocy w amerykańskiej armii motywowana homofobicznie (Sontag 2010; Butler 2011).

Literatura poradoznawcza dotycząca problemów chłopców i młodych mężczyzn zorientowana ku praktycznym celom zasługuje na odrębne potraktowanie. Literatura ta obok mediów stała się jednym z narzędzi wzniecania paniki moralnej wokół szkolnych niepowodzeń tej grupy uczniów oraz utrwalania przekonań o kryzysie męskości. Najliczniejszą grupę publikacji skupił problem szkolnej agresji chłopców: sposobów jej pacyfikowania, kanalizowania, radzenia sobie $\mathrm{z}$ nią w codziennej pracy szkoły, rodziny i najbliższej społeczności. Innym mocno reprezentowanym wątkiem $\mathrm{w}$ literaturze poradoznawczej jest terapeutyczny aspekt pracy z chłopcami i młodymi mężczyznami, dotyczący dwóch przenikających się wymiarów: uczenia się i jego wyników (z zaznaczającym się proble- 
mem porażki szkolnej chłopców) oraz psychologicznych i społecznych konsekwencji ich porażki. Skuteczne zapobieganie i niwelowanie rozmiarów porażki szkolnej chłopców miałoby, zdaniem autorów, zbawienne skutki dla zahamowania kryzysu męskości, ograniczenia wciąż narastającej agresji szkolnej, w nowych, nieznanych - lub nieopisywanych dotąd - postaciach, jak na przykład szkolne strzelaniny, dla wyeliminowania problemu przemocy ze względu na płeć, seksualność i pochodzenie etniczne oraz złagodzenia problemu cyberprzemocy (Martio, Berrill 2003). Autorzy wielu publikacji skierowali konkretną ofertę programów profilaktycznych i terapeutycznych związanych z edukacją antyseksistowską. Do najważniejszych prac tego nurtu można zaliczyć Challenging Macho Values (Salisbury, Jackson 1996) czy liczne prace Jacksona Katza, na przykład Paradoks Macho (Katz 2012). Prace te oferują kadrze nauczycielskiej wiele konkretnych strategii i rozwiązań do zastosowania w codziennej praktyce, wiele wskazówek natury organizacyjnej, a także wskazania dla szkolnych psychologów z myślą o minimalizowaniu chłopięcej agresji.

W literaturze zorientowanej na skuteczne działania zmierzające do rozwiązania problemu niepowodzeń szkolnych autorzy najczęściej sugerują: zastąpienie izolowanych zagadnień szkolnych zagadnieniami blokowymi, zwrócenie szczególnej uwagi na dobór kadry nauczycielskiej (w miarę możliwości dążyć do zwiększenia męskiej reprezentacji), szkolenie przyszłej kadry nauczycielskiej z uwzględnieniem problematyki gender, skuteczne motywowanie do zmiany, wypracowywanie sposobów pracy z chłopcami, które nie naruszają ich godności i nie czynią ich winnymi niepowodzeń, rozwijanie kompetencji krytycznego czytania znaczeń męskości w tekstach kultury (Mills 2000).

Zwiększone zainteresowanie szkolnymi problemami chłopców znalazło swój oddźwięk również w badaniach feministycznych, głównie z uwagi na retorykę backlashu i wpisany w nią płciowy rewanżyzm, które dawały się zauważyć w wielu pracach spod znaku debaty „what about the boys?”. Najbardziej interesujący aspekt prac feministycznych poświęconych chłopcom wiąże się z pytaniem o chłopców jako ofiary represyjnego działania szkoły. Pytanie to nie tylko otwierało debatę nad rzeczywistymi wymiarami szkolnej opresji tej grupy uczniów, ale też było głosem w dyskusji dotyczącej finansowania programów edukacyjnych (antydyskryminacyjnych i równościowych), których beneficjentami stali się chłopcy jako „nowe ofiary” szkolnej opresji. W pytaniu tym nie było sugestii związanych z podważeniem słuszności tezy o opresyjnym treningu męskości. Było ono motywowane dążeniem do oszacowania, jakim grupom chłopców szkolne wsparcie jest rzeczywiście najbardziej potrzebne, czy niektórym z nich status „nowych opresjonowanych" nie został przyznany na wyrost, co miało znaczenie w perspektywie poważnych redukcji nakładów finansowych na edukację i działania społeczne w wielu krajach dotkniętych gospodarczym kryzysem (Arnot, Gubb 2001; Yates 2000).

Poza wskazanymi tematami w wielu publikacjach feministycznych pojawiło się również pytanie o społeczną cenę paniki moralnej związanej ze szkolnym funkcjonowaniem chłopców. Chodziło tu szczególnie o werbalizowane w dyskursie 
publicznym społeczne obawy, które zostały wywołane przez sukcesy szkolne dziewcząt (przymuszające je do tłumaczenia się z sukcesu, a wręcz przepraszania za sukces) oraz o publiczne zapowiedzi polityków i działaczy edukacyjnych dotyczące „zapobiegania” sukcesom dziewcząt w przyszłości, ponieważ - na co wskazywało wielu obrońców nowych opresjonowanych - sukcesy dziewcząt wiktymizują chłopców (Epstein i in. 1998). Inny typ feministycznej krytyki wiązał się z postulowanymi środkami naprawczymi, które miałyby wzmocnić chłopców: zwłaszcza z proponowanym remedium w postaci klas/szkól jednopłciowych. Jak wskazywały Kenway i Willis, społeczne konsekwencje szkolnej segregacji mogą okazać się przeciwne do spodziewanych. Zamiast poprawy szkolnych osiągnięć chłopców (jak miało to miejsce w przypadku dziewcząt) należy spodziewać się ich pogorszenia z powodu problemów natury dyscyplinarnej, nasilonej przemocy na tle rasistowskim i homofobicznym. Jak przekonują autorzy, szkolne problemy dziewcząt i chłopców mają odmienne uwarunkowania historyczne i społeczne, inną dynamikę i inny przebieg, w wymiarach ilościowym i jakościowym. Poza tym edukacyjne ruchy na rzecz segregacji $\mathrm{w}$ nauczaniu niosą antydemokratyczne przesłanie: konieczności oddzielania, niemożności bycia razem, gettoizacji, zamkniętego, podzielonego społeczeństwa. Przesłanie to musi być wnikliwie analizowane we współczesnych społeczeństwach przywiązanych do demokratycznych wartości (Kenway, Willis 1998).

Wspólnym mianownikiem prac feministycznych i prac, dla których krytyka feministyczna była jednym ze źródeł teoretycznych, jest przekonanie o zgubnej w skutkach praktyce "ekonomizacji” osiągnięć szkolnych w aspekcie płci: dziewczęta powinny stracić, by mogli zyskali chłopcy. Ich wspólnym przesłaniem jest demokratyczna troska o poszukiwanie nowych dróg i sposobów osiągania społecznej równości i sprawiedliwości, dzięki którym zyskują wszyscy.

Rekonstrukcja pola problemowego debaty o szkolnym funkcjonowaniu chłopców, która to debata przetoczyła się w społeczeństwach Zachodu ponad dekadę temu, ma w polskim kontekście społeczno-kulturowym i edukacyjnym istotne znaczenie. Po pierwsze, na naszych oczach dokonuje się istotna zmiana w genderowych wzorach szkolnego sukcesu na niekorzyść chłopców. Po drugie, od końca 2013 roku w Polsce wyraźnie słyszalny jest język paniki moralnej wokół tzw. ideologii gender i genderyzmu². Jaka jest przyczyna konserwatywnych, antyrównościowych postaw ujawniających się po dwudziestu pięciu latach okresu polskiej transformacji? Jaka jest geneza antymodernizacyjnego zwrotu $\mathrm{w}$ kierunku „natury"? Czy jest on zakorzeniony wyłącznie lokalnie?

\section{Kryzys równości i powrót naturalizmu}

Trzydzieści lat temu wielką nadzieją dla kobiecych emancypacyjnych ruchów społecznych był równy podział pracy i władzy. Równościowe nadzieje zawierały

\footnotetext{
2 Pojęcia te nie zostały zdefiniowane $\mathrm{w}$ tej debacie; są znaczeniowo puste.
} 
się w formule: połowa świata (dla kobiet) w zamian za połowę domu (dla mężczyzn). Mogło się wydawać, że polityczna, społeczna i kulturowa praca (edukacja, socjalizacja) przybliża kobiety do tego celu, a z pewnością, że jesteśmy na ostatniej prostej jego osiągnięcia. Od początku lat 90. XX wieku w Europie, USA i Australii narasta przekonanie o poważnym kryzysie równości o fundamentalnym znaczeniu w związku z serią kryzysów gospodarczych. Jak się okazuje, ich skutki (głównie niepewność na rynku pracy i wyparcie kobiet z rynku pracy, zwłaszcza tych o najniższym kapitale edukacyjnym i ekonomicznym) poważnie zahamowały równościowe dążenia zaznaczające się w poprzednich dziesięcioleciach. Elisabeth Badinter wskazuje, iż następujące po sobie kryzysy gospodarcze sprzyjają intensyfikacji psychologicznych dyskursów protekcjonistycznych w stosunku do mężczyzn (np. podkreślanie tożsamościowego znaczenia i wartości pracy mężczyzn, bezrobocie ojca przedstawiane jako bardziej destrukcyjne w skutkach dla rodziny niż bezrobocie matki itp.) oraz dyskursów odsłaniających nowe obowiązki kobiet-matek wobec dzieci (Badinter 2013, s.11). Taki splot dyskursywny wzmaga jedynie opór mężczyzn wobec wprowadzenia równości.

Jak wskazują dane statystyczne, kobiety w Europie wciąż wykonują 3/4 obowiązków domowych. Niemniej kryzys gospodarczy nie jest jedyną przyczyną utrzymywania się nierówności. Poważniejszą przyczyną jest kryzys tożsamościowy, jakiego - jak zaznacza Badinter - nie było dotychczas w historii ludzkości (Badinter 2013, s. 35). Jego istotą jest przekonanie o nieistnieniu tradycyjnych „dogmatycznych” granic i podziałów, które zabezpieczały poczucie tożsamości kobiet i mężczyzn. Cóż pozostało z tych dogmatyzowanych różnic, od kiedy mężczyźni i kobiety mogą wykonywać te same role i zadania w sferze publicznej i prywatnej?

Kolejne kryzysy ekonomiczne spowodowały, iż ponownie pojawiła się zapomniana ideologia naturalizmu: coraz częściej przypomina się o szczególnym związku kobiet z naturą, o instynkcie macierzyńskim jako istocie kobiecości itp. Tym razem naturalizm pojawia się jednak jako dyskurs postępu i nowoczesności: ekologia (w tym ekologiczny model macierzyństwa odrzucający wszystko to, co sztuczne w świecie dziecka: kosmetyki, środki higieny, proszki do prania, przetworzoną żywność dla dzieci, pieluchy jednorazowego użytku na rzecz produktów naturalnych), etologia ponownie wprowadzająca kwestię instynktu macierzyńskiego do sfery nauki oraz feminizm esencjalistyczny opisujący istotę kobiecości (np. kobieca etyka troski wnikliwie przeanalizowana przez Carol Gilligan (2015). Obecnie stawką dyskursów naturalistycznych jest dobrostan dzieci i przyszła harmonia społeczna.

Obecnie dyskurs natury otoczony jest dodatkowo aurą nowoczesności i etyki. Jak za czasów Jeana-Jacquesa Rousseau próbuje się przekonać kobiety (i nie tylko) do odnowienia kontaktu z naturą i powrotu do korzeni - naturalnej roli matki. Natura staje się tu gwarantem minionego podziału władzy i pracy. Jest tożsama z pewnym porządkiem rzeczy, który odszedł do przeszłości, lecz daje nadzieję na odświeżenie - wystarczy sięgnąć do źródła. Zatem obecnie kobiety są zachęcane do oddania połowy świata w zamian za odzyskanie całości domu. 


\section{Natura i posthumanizm}

XXI wiek został ogłoszony wiekiem biotechnologii, co w kontekście teorii społecznej pociągnęło za sobą szereg istotnych zmian w myśleniu o tym, kim jesteśmy wobec nieludzkich form życia oraz technologii (Bakke 2010, s. 7).

Dynamicznie rozwijający się posthumanizm przyjmuje demaskatorski rys krytyczno-emancypacyjnych teorii społecznych, wskazując na konieczność detoksykacji myśli zachodniej od idei natury. Bruno Latour wśród pełnionych przez naturę funkcji na pierwszy plan wysuwa funkcje ideologiczne - uprawomocnianie idei porządku społecznego oraz antagonistyczne umiejscowienie $\mathrm{w}$ stosunku do sfery społecznej, co następnie umożliwia zaistnienie szeregu fałszywych dychotomicznych podziałów, tak jak na przykład: aktywne podmioty (ludzie) i pasywne przedmioty (rzeczy) oraz wiele innych. „Ludzie zachodu zrobili z natury wielkie przedsięwzięcie, dogłębną polityczną gigantomachinę i nieustannie posługiwali się naturą przy określaniu porządku społecznego" (Latour 2009, s. 70-71). Posthumaniści zajmują się jednak znacznie intensywniej problematyką konstruowania granic dzielących naturę i kulturę - problematyką podziału i powstania dwóch fundamentalnie odmiennych stref ontologicznych, na mocy którego to podziału po jednej stronie umieszczeni zostali ludzie, ich interesy, władza i polityka, a po drugiej-nieludzie i przedmioty. Latour zauważył, że nowożytność uznano za początek i tryumf humanizmu, za "narodziny człowieka” i podmiotu. Utrzymuje on jednak, że przemilczanym aspektem tego procesu są narodziny nieczłowieka, narodziny rzeczy, czyli przedmiotów i zwierząt, uznanych za coś fundamentalnie odmiennego od ludzi (Latour 2011, s. 13). Istotę posthumanistycznego projektu można zrozumieć jako próbę poszukiwania powiązań, ciągłości i kooperacji między różnymi typami bytów i artefaktów poza poznawczą ramą wyznaczaną przez ów fundamentalny podział.

Rok 2000 ogłoszono rokiem przełomowym ze względu na stopień zaawansowania badań nad ludzkim genomem (kodem kodów ludzkiej natury), w efekcie których staje się możliwe skuteczne sekwencjonowanie kodu genetycznego, jego modyfikowanie oraz syntetyzowanie (generowanie), w następstwie którego mogą powstawać minimalne do utrzymania przy życiu genomy pełniące funkcje „wymiennych części" (komponentów DNA), staje się możliwe konstruowanie całkowicie nowych komórek i syntetycznych biomolekuł. W 2010 roku Craig Venter (jeden z przedstawicieli tzw. biologii syntetycznej) stworzył pierwszą samoreplikującą się syntetyczną bakterię, a zatem powiodła się operacja stworzenia życia z nieżywnych elementów. Postęp biotechnologii, inżynierii genetycznej czy nanotechnologii wiąże się z powołaniem do życia istnień o niejasnym statusie: organizmów transgenicznych, hybryd, organów i tkanek hodowanych do transplantacji, linii komórkowych, komórek macierzystych, mrożonych embrionów, chimer, istnień semi-living utrzymywanych przy życiu wyłącznie dzięki nowoczesnym technologiom (Catts, Zurr), jak biomasa - rodzaj „rozszerzonego ciała”, wykorzystywanego w laboratoriach. O ile organizm (ciało) nie może istnieć bez tkanek 
i komórek, to współcześnie, dzięki postępom biotechnologii, tkanki i komórki mogą już swobodnie obyć się bez ciał. Rzecz jasna owe postępy spotykają się z falą krytyki i oburzenia ze strony biokonserwatystów, obawiających się konsekwencji tego rozwoju (największy lęk wywołuje obraz „hodowania ludzi” o specyficznych właściwościach). Niezależnie od tych obaw można jednak zaobserwować wzrost zainteresowania problematyką liminalnego życia, kwestionującego granice między indywidualnymi organizmami oraz elementami ludzkimi i nieludzkimi (Bakke 2010, s. 76), zarówno jeśli chodzi o sferę nauki, praktyki artystycznej, jak i kulturę popularną. Liminalne życia testują granice funkcjonujących taksonomii: społecznych, etycznych, biologicznych, gatunkowych czy ekonomicznych. Ponieważ medyczne interwencje zmieniają nasze sposoby zapładniania, rodzenia się, wzrastania, starzenia i umierania - liminalne życia otaczają nas w naszych szkołach, rodzinach, życiu zawodowym, instytucjonalnym i w reprezentacjach wszędzie gdzie forma lub przebieg życia ulega zmianom pod wpływem biomedycyny.

Nikolas Rose, opisując współczesność, zwraca uwagę, że jesteśmy w centrum istotnego kulturowego procesu, który niepostrzeżenie prowadzi do szeregu transfiguracji, dzięki którym zaczynamy dostrzegać liczne powiązania, zależności i ciągłość w miejscach, w których uprzednio dostrzegaliśmy wyłącznie granice (Rose 2011). Do najistotniejszych konsekwencji związanych bezpośrednio z zaistnieniem posthumanizmu należy zbiór pytań o status człowieka wobec nieludzkich form życia oraz artefaktów. O ile panuje zgoda odnośnie do faktu utraty przez człowieka wyróżnionego (szczególnego czy nadrzędnego) statusu, o tyle poszczególnych autorów różni interpretacja tego faktu. Niektórzy głoszą zatem "kres człowieka”, wiążąc go z dynamicznym postępem biotechnologii i technologii cyfrowych, wskazując, że cyborg (ulepszony technologicznie człowiek-maszyna) lub postczłowiek stanie się nowym normatywnym „punktem docelowym” stechnicyzowanego rozwoju (More 2014). Inni z kolei podtrzymują koncepcję "człowieka zdecentrowanego" (przemyślanego poza konceptualną ramą antropocentryzmu) - organizmu ulokowanego w sieci witalnych współzależności z nieludzkimi formami życia i technologiami (Bakke 2010, s. 8). Warto jednak zaznaczyć, że człowiek jako taki nie znika z horyzontu refleksji społecznej czy filozoficznej, ale niewątpliwie zanika uprzywilejowana pozycja ludzka, wyróżniana ze względu na kryteria przynależności gatunkowej. Intensyfikacja dyskursu posthumanistycznego postępująca wraz z dynamicznym rozwojem biotechnologii oraz technologii cyfrowych ma niebagatelny wpływ na sposób, w jaki ujmuje się samo życie i jego przebieg. Technologie cyfrowe, postępy farmakologii, inżynieria genetyczna, biologia molekularna wyraźnie sprzyjają podziałowi na to, co powstało samo (natura) i na to, co zostało zrobione (kultura). Jednocześnie liczne biotransfiguracje (na przykład działania związane z modyfikowaniem genomów, których efektem jest istnienie organizmów transgenicznych) czy technologiczne nadzieje pokładane w skonstruowaniu lepszego ludzkiego wcielenia - „wtopienia się" ludzi w świat rzeczy (życie in silico) sprzyjają włączeniu nieludzkich innych (zwierząt i przedmiotów) w domenę sprawczości (działania społecznego) oraz domenę 
etyki. Jak już zaznaczałam wcześniej, posthumanizm w swych licznych orientacjach (biokonserwatywnej lub transhumanistycznej) i odczytaniach (optymistycznych i pesymistycznych) kwestionuje dogmatyczne podziały funkcjonujące w obrębie zachodniej myśli społecznej dotyczące aktywnie działających podmiotów (ludzi) i pasywnych przedmiotów, komplikując pojęcie sprawczości i obejmując nim podmioty inne niż ludzie. Jednym z najciekawszych przykładów takiego ujęcia jest teoria aktora-sieci. Latourowska teoria jest stosunkowo dobrze opisana w literaturze polskojęzycznej, zatem odniosę się do jej najważniejszych elementów. Jej najistotniejszym posthumanistycznym rysem jest uznanie relacyjności bytów, ich egzystowania w relacjach oraz definiowania ich właściwości, atrybutów czy cech nie w esencjach („,stabilnych naturach"), ale w synergii - nabierania różnych właściwości (atrybutów czy cech) w heterogenicznych sieciach łączących różne rodzaje materiałów i bytów. Jak wskazuje Latour, rzeczywistości nie da się odnaleźć w esencjach, ale w połączeniach i mieszaninach, w kłączach kultury i natury, gdzie ludzie i nieludzie pozostają w bliskich relacjach kooperacji. Stąd właściwości, atrybuty i esencje wynikają jedynie z efektu włączenia w określoną sieć, skąd oddziałują na pozostałe jej elementy (Latour 2011). Neomaterialistyczny rys teorii Latoura ujawnia się również w założeniach dotyczących działania społecznego: sprawczym aktorem i aktantem mogą być zarówno rzeczy, ludzie oraz istoty nieludzkie. Latour kreśli zatem radykalnie nowy porządek demokratyczny, który nikogo nie pomija w sieciach społecznego sprawstwa, który nikogo i niczego nie wyklucza, gdyż wszystko jest częścią jakiejś sieci i wszystko jest włączone $\mathrm{w}$ określony program działania. $\mathrm{W}$ tym znaczeniu posthumanizm, a w jego ramach neomaterializm, można określić mianem nowej teorii politycznej, której istotą jest poszerzona koncepcja demokracji obejmująca podmioty inne niż ludzie (Olsen 2010, s. 592).

Posthumanistyczne pytania o życie, ujmowane poza ramą dogmatycznych dla Zachodu opozycji natura-kultura, ludzkie-nieludzkie, żywe-martwe, nawiązują do tradycji etycznych wypieranych przez tradycyjną humanistykę. Posthumanizm jest więc również próbą nakreślenia propozycji etycznej konstruowanej z pominięciem antropocentryzmu. Na szczególną uwagę zasługuje w tej perspektywie koncepcja Rosi Braidotti, afirmująca zoe - generatywną witalność pozaludzkiego i przedludzkiego życia, toczącego się niezależnie i bez względu na racjonalną kontrolę (Braidotti 2006, s. 37). Koncepcja Braidotti jest utrzymana $\mathrm{w}$ duchu neomaterialistycznym: jest to koncepcja witalistyczna i egalitarna. Nie jest ona typem relatywistycznej czy nihilistycznej koncepcji etycznej. Jej istotą jest materialistyczne ujęcie podstaw życia wcielonego i symbiotycznie powiązanego z innymi ciałami (Bakke 2010, s. 88). Życie w egalitarnym sensie (każde życie) toczy się bez względu na indywidualne śmierci, mnoży się wszędzie w intensywności i wielości form. Nie jest ono pozbawione przemocy, ale jest też głęboko współczujące. Zatem toczy się zawsze na krawędzi życia i śmierci. Mimo iż konkretne, indywidualne organizmy giną, życie (zoe) wciąż trwa. Wraz ze swoją dynamiką rozmnażania, odżywiania, fuzji, infekowania, umierania lub zabijania zoe rozgrywa się poza moralnymi wyborami i decyzjami jednostek. Nie ma zatem, jak przeko- 
nuje autorka, istotnej różnicy między złośliwym namnażaniem się komórek nowotworowych a łagodnym namnażaniem się komórek w czasie ciąży. Życiu nieuchronnie towarzyszą śmierć i nieśmiertelność (Braidotti 2006, s. 223).

Analizowanie sposobów konstruowania natury i jej funkcji pełnionych wobec tego, co społeczne zaowocowało powstaniem nieantropocentrycznych koncepcji polityki i etyki, których istotą (w obszarze teorii i praktyki społecznej) jest próba poszukiwania pozytywnych, produktywnych sposobów zrównoważonego współistnienia, współdziałania i wymiany zachodzących między istotami nieludzkimi, ludźmi i przedmiotami. Na posthumanistycznym gruncie sformułowano też polityczne teorie radykalnej demokracji, sprawiedliwości i równości rozszerzonej i obejmującej podmioty inne niż ludzie. Z jednej strony mamy więc działanie języka paniki moralnej, który jest symptomem nieradzenia sobie współczesnych społeczeństw z problematyką różnicy i różnorodności kulturowej w obrębie społeczności, w którym to języku słychać zapowiedź eliminacji różnic w imię „natury”, $\mathrm{z}$ drugiej zaś strony jesteśmy konfrontowani z potężnym wyzwaniem $\mathrm{w}$ postaci stopienia „natury” i technologii, który to związek mocno przekształca fantazje o naszej "gatunkowej czystości”. Proces ten przyniesie w najbliższych latach istotne konsekwencje dla teorii społecznej, a w szczególności dla możliwości teoretyzacji odmienności, podmiotowości oraz teorii emancypacyjnych.

\section{Literatura:}

Arnot M., Gubb J, 2001, Adding value to boys' and girls' education, A gender and achievement project in West Sussex, West Sussex Country Council.

Badinter E., 2013, Konflikt: kobieta i matka, Wydawnictwo Naukowe PWN, Warszawa.

Bakke M., 2010, Bio-transfiguracje, Sztuka i estetyka posthumanizmu, Wydawnictwo Naukowe UAM, Poznań.

Biddulph S., 1998, Raising boys: Why boys are different and how to help them become happy and well-balanced men, Finch, Sydney.

Braidotti R., 2006, Transpositions: On Nomadic Ethics, Polity Press, Cambridge.

Butler J., 2011, Ramy wojny. Kiedy życie godne jest opłakiwania, Wyd. Książka i Prasa, Warszawa.

Catts O., Zurr I., Towards a New Class of Being: The Extended Body, http://www.tca.uwa.edu. au/atGlance/pubMainFrames.html [dostęp: 30.12.2014].

Epstein D., Elwood J., Hay V., Maw J., 1998, Failing boys? Issues in gender and achievement, Open University Press, Buckingham.

Faludi S., 1991, Backlash: The undeclared war against American women, Anchor Books, New York.

Faludi S.,1999, Stiffed: The betrayal of the American man, William Morrow, New York.

Farrell W., 1993, The myth of male power: Why men are the disposable sex, Simon and Schuster, New York.

Gilligan C., 2015, Innym głosem. Teoria psychologiczna a rozwój kobiet, Wydawnictwo Krytyki Politycznej, Warszawa. 
Gurian M., 2001, Boys and girls learn differently! A guide for teachers and parents, Jossey Bass, San Francisco.

Katz J., 2012, Paradoks Macho, Czarna Owca, Warszawa.

Kenway J., Willis S., 1998, Answering back: Girls, boys and feminism in schools, Routledge, London.

Kimmel M.S., 2000, What about the boys?, WEEA, No. 1-2.

Kindlon D., Thompson M., 2000, Raising cain: Protecting the emotional life of boys, Ballantine Books, New York.

Kopciewicz L., 2012, Matematyka, wtadza i pole wytwarzania kultury, Difin, Warszawa.

Latour B., 2009, Polityka natury, Wydawnictwo Krytyki Politycznej, Warszawa.

Latour B., 2011, Nigdy nie byliśmy nowocześni, Oficyna Naukowa, Warszawa.

Lingard R., Douglas P., 1999, Men engaging feminisms: Pro-feminism, backlashes and schooling, Open University Press, Buckingham.

Mac an Ghaill M., 1996, “What about the boys?", Schooling, class and crisis masculinity, „Sociological Review", Vol. 44.

Marry C., 2007, Edukacja dziewcząt w Europie - niedokończona rewolucja [w:] Ch. Ockrent (red.), Czarna księga kobiet, Wydawnictwo WAB, Warszawa.

Martino W., Berrill D., 2003, Boys, schooling and masculinities: Interrogating the "right" way to educate boys, „Educational Review”, Vol. 2.

Maruani M., 2007, Życie zawodowe: parytet bez równości [w:] Ch. Ockrent (red.), Czarna księga kobiet, Wydawnictwo WAB, Warszawa.

Melosik Z., 2006, Kryzys męskości w kulturze wspótczesnej, Oficyna Wydawnicza Impuls, Kraków.

Mills M., 2000, Issues in implementing boys' programme in schools: Male teachers and empowerment, "Gender and Education", Vol. 2.

More M., 2014, The Extropian Priniciples. A Transhumanist Declaration, http://vency.com/EXtropian3.htm [dostęp 30.12.2014].

Olsen B., 2010, Kultura materialna po tekście: przywracanie obecności rzeczom [w:] Teoria wiedzy o przeszłości na tle wspótczesnej humanistyki, red. E. Domańska, Wydawnictwo Poznańskie, Poznań.

Pollack W., 1998, Real boys: Rescuing our sons from the myths of boyhood, Random House, New York.

Rogers P., Kaiser G., 1995, Equity in Mathematics Education. Influences of Feminism and Culture, London and New York.

Rose N., 2011, Polityka życia samego, „Praktyka teoretyczna” nr 2-3.

Salisbury J., Jackson D., 1996, Challenging macho values: Practical ways of working with adolescent boys, Falmer, London.

Soin M., 2011, Fakty, wartości i panika moralna, „Studia Socjologiczne”, nr 2.

Sommers C.H., 2000, The war against boys: How misguided feminism is harming our young men, Simon and Schuster, New York.

Sontag S., 2010, Widok cudzego cierpienia, Wyd. Karakter, Warszawa.

Weaver-Hightower M., 2003, The "boy turn" in research on gender and education, "Review of Educational Research", Vol. 4.

Yates L., 2000, The "facts of the case": Gender equity for boys as a public policy issue [w:] Lesko N. (ed.), Masculinities at school, Sage, Thousand Oaks.

Zielińska I., 2004, Media, interes i panika moralna. Nowa kategoria socjologiczna i jej implikacje, „Kultura i Społeczeństwo" nr 4. 


\section{Summary}

Nature and equality: moral panic around 'failing boys' in nineties in the perspective of questions about 21st century feminism and posthumanism

The article explores 'failing boys' discourses that circulate in the Western media and how this relates to policy and practice, ultimately shaping the gender politics of schooling. It explores what crisis of masculinity means, what gender politics are and why the idea of moral panic provides a critical analytical tool for looking at current debates around gender, democracy, equality, sexuality, and education in Poland.

\section{Keywords}

nature, equality, feminism, masculinity crisis, posthumanism

\section{Słowa kluczowe}

natura, równość, feminizm, kryzys męskości, posthumanizm 
